\title{
フロレス島少ダ紀行〔Herbert Lehmann]
}

Die Landschaft Ngada auf Flores

(Eine länderkundl'che Skizze aus dem Sundainseln)

Geogr. Zeitschr. 41 (r935) H. 9, 339-352

Alang-Alang 草の荒原の彼方に蜿蜒と連る舊火山體との單調起破つて㢭える新火山 錐の群，山陵線附近に僅かに残る熱帶原生森，モンスーンが雨雲を寉す下に生える

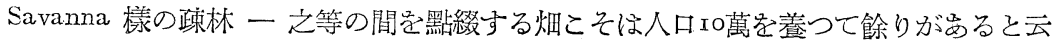

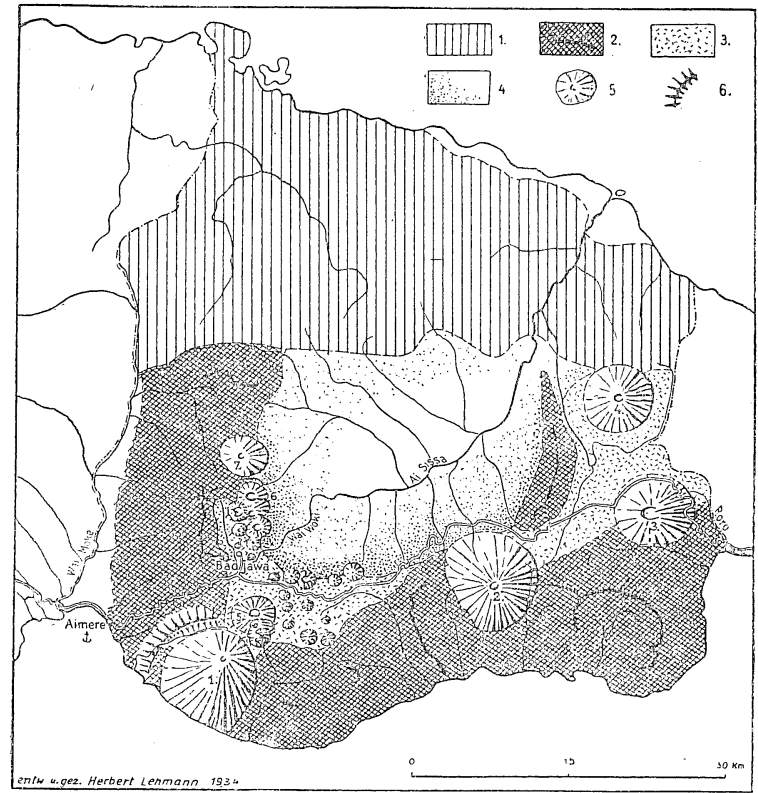

z. 第三紀傾動地塊

2. 解析をちけた蕓火山體

3. 凝灰岩䁷
第 I 圖 地 勢 圖

4. 凝灰岩及燃岩に圈をれた Interkollin 盈地

5. 新火山雓
へば，此の地ぶ島中

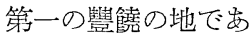
る事分淔肯出來るだ ら弓。（符 I圖，第 2 圖)上民は草原に猪， 鹿军追ひ，又草原军 燒いて玉罚泰 (陸稻 の間作）と豆類との 輸作空する。畑は夫 ハ所有圭が岕つて， 個人の㩲利は既に認 めら凯てるるとは云 へ, 一步竹林に園采 れた彼等の聚落に足 定踏久大れると，中 央の空地に嚴然と存 する祖先の靈への象

*Flores 島は東より順次 Mangarai, Ngada, Endeh, Maoemere, Larantoeka の5 州 に分たる。 


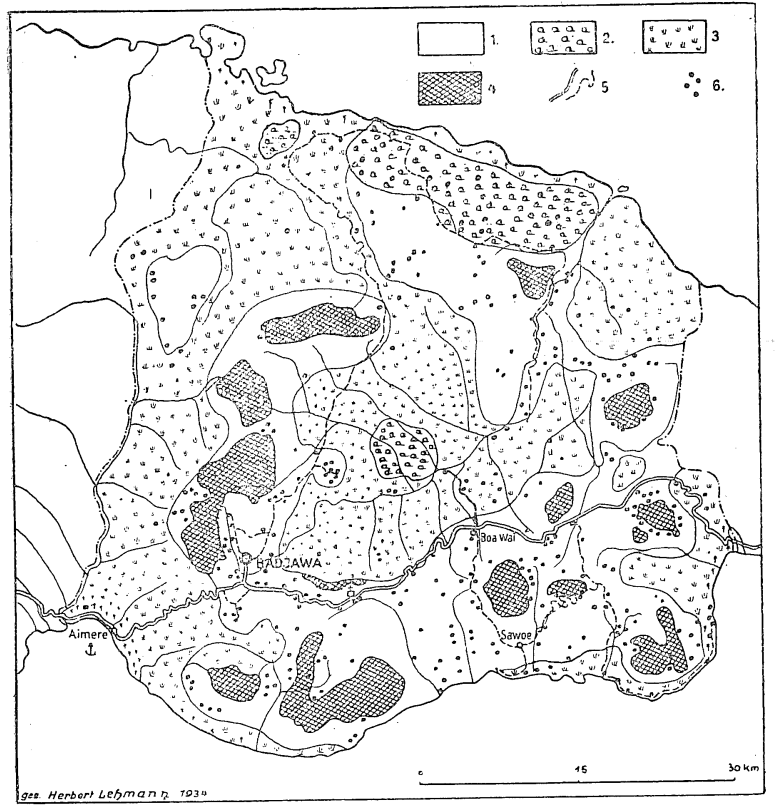

節 2 圆 景 觀 圖
r. 畑
3. Alang-Alang 草原
2. Savanna 栐疎不木
4. 原生森

徵物註，彼等個々门生 活範園学自ら限定して しまふ。

聚落分布は判然と 3 ケ所に密集してるるの が特徴である(第2圖)。 此の原因は自然的條件 と云ふよりは寧ろ，翻 組織の特徵の反映と見 るべきで，此の地に移 住して來た I 憲が，蕃 として各々適した土地 に定佳した結果と見る の方晏當で岕る。1908 年オランダ人が此の 地定征服直後, Van Stavern 氏がNgada 族 のI4村に就て調べた

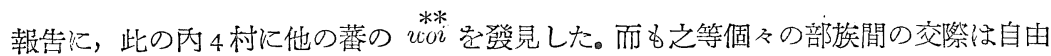
で，道德律，慣替等の點で何等夌障が起らない，と報じてるるのは，此等諸蕃の定住 以前の源觉エつである事堂暗示するものの如く，現在見る樣に Ai Sissa河を中心に，

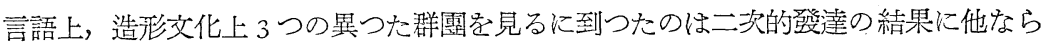
ない樣で岕る。而もメラネシア琵素といふ大觀點から眺める時, Ngada と Mangarai の境ばその最西端の境界線に大體一致し，此の地の土民の人種學的位置は茥だ重要で ある。

數年前迄は，交通のホ便と，山間の土民の兇惡性とのために，山地の旅行は不可能

**部族 (ucoi）の男子の祖先に捧げられたるのはnadu（圆錐形の屋根を有する柱）で あり，女子の租先へは $b a g a$ (四注草葺の小家屋) nadu の父には peo（細長い石） ボ象徴物となつてるる。 
事に近かつた此の地子近年 Aimere Endeh 間を結ぶ道路の完成以來，急テンポに歐洲 文明の侵潤を見，Bodjawa 附近定中心として刻及植民地風に化しつつあり，竹林に圍 まれそ土民の村々の間に, 林を持た奴敉會の尖塔, 農場のトタン屋根一此の農場の製品 は附近の島々にタる宣敎師達の需要学充してタる一が並び奇妙な對照定なすに到つた。

田上 正典

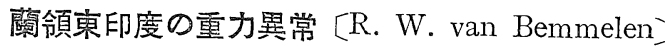

Über die Deutung der Schwerkraftanomalien in Niederländisch-Indien Geol. Runds., 26 (I935), H. 3, r99-226

1923一I932 年に V. Meinesz の努力によつて海洋の重力測定が行はれた結果, Malay 列島弧の外側には著しい重力の均衡鿓異常帶が存在しアアソスタシーが成立してる ない事か知られた。Meinesz はこの現象金 Einknickungstheorie (地殸の折れ込み說) によつて說明せんとし，I934 年に曚地域に關する Umbgrove の地質的㸴究 Kuenen の海底地形調查と共に發表したが 3 方面の政究は相互の密接な關係学示し, 此の現象 の說明はすべてを考慮した綜合的のものでなければならぬと考いる。

Meinesz の說はこの重力均衡異常は補貲せられざる表面起伏に歸し得ず，地下に質 量不足が岕つてこれはSial が Sima 層中に折れ込んで比重小なる部分学形成してる る篇であるとなした。即ら Sima が放射能性の熱学不平均に蓄積した雹に對流莸起し （速度 $I$ 年 $I \mathrm{~cm}$ ）その祭 2 つ對流の收斂部に於て表面のSial 污引き込まれて重力異 常の源をなすと云ふので要る。後にこの地帶が地殼均衡運動の爲全體として隆起する そ折れ込み部分の兩側に正異常帶艺生ずる。又重力負帶は Malay 島弧の外側非火山

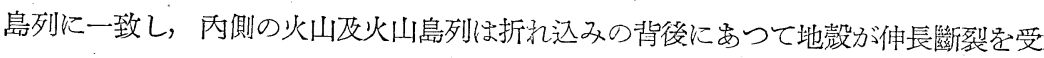
けた爲生じたものであると云ふ。

Meinesz の說には多くの疑問があり殊に彼の假定する 400km の深さに支ぶ對流に 於ては Sima が物理化學的に非常な狀態變化を受けその性質及び比重学變化して對流 定奶げる惧れが昰る。此處には種々の疑問の紹介学略して著著の Undationstheorie（糿

(1) Vening Meinesz, F. A., Umbgrove, J. W. F, Kuenen, PH. H. : Gravity Expedition at Sea (I923-I932) 2. : Report of the gravity expedition in the Atlantic and the interprtation of the results-Pub. of the Netherl. Geod. Comm. Waltmann, Delft I934. 